\title{
FENOMENA MIKRO-SELEBRITI DI MEDIA SOSIAL (STUDI ETNOGRAFI VIRTUAL VIDEO VIRAL AKUN @HELENJUNET TANGGAL 22 MARET 2019 PADA PENGGUNA INSTAGRAM)
}

\author{
Rizqiani Aulia, Ade Irfan Abdurahman \\ airfan@unis.ac.id \\ Prodi Ilmu Komunikasi, FISIP Universitas Islam Syekh Yusuf Tangerang
}

\begin{abstract}
ABSTRAK
Penelitian ini bertujuan untuk mengetahui bagaimana kecenderungan perilaku dan budaya siber pada pengguna instagram saat dihadapkan dengan tren mikro-selebriti video viral milik akun instagram @helenjunet yang di upload pada 22 Maret 2019. Penelitian ini menggunakan studi Etnografi Virtual yang membahas tentang Cyberculture dan menggunakan Level Analisis Media Siber (AMS) dan Tipologi David Bell untuk menguraikan. Adapun hasil penelitian ini menunjukan bagaimana aktifitas di ruang siber dan terjadi terus menerus dan membentuk budaya pengguna. Selain itu peneliti juga menemukan beberapa motif yang menjadi alasan para pengguna instagram menonton dan mengikuti tren video viral. Pertama, motif hiburan dan kedua, motif keingintahuan
\end{abstract}

Kata Kunci: Mikro-Selebriti, Video Viral, Instagram, Etnografi Virtual, Analisis Media Siber

\section{ABSTRACT}

This study to know how trends of behavior and cyberculture on Instagram users, when confronted with micro-celebrity trends of viral video, belong to @ helenjunet Instagram account that uploaded on 22nd March 2019. This research uses Ethnographic Virtual studies that discuss cyberculture by Analysis of Media Cyber Level (AMS) and the typology of David Bell to elaborate. And the results of the study showed how activity in cyberculture and to continue happens and shaping the user's culture. And addition researchers also found some motive as a reason for Instagram users to watch and follow the trend of viral video. First, the motive of entertainment and second is the motive of curiosity.

Keywords: Keywords: Micro-celebrity, Viral Video, Instagram, Ethnographic Virtual, Analysis of Media Cyber Level (AMS)

\section{PENDAHULUAN}

Fenomena tren micro-celebrity di media sosial belakangan ini sangat marak ditemui, hal itu dapat dilihat dari berbagai postingan di sosial media terutama pada postingan video yang bisa mendadak viral hanya karena pembuatnya melakukan hal tertentu yang dapat menarik atensi atau perhatian publik. 
Salah satu video milik akun@helenjunet yang menjadi viral dan direupload oleh akunakun tersebut adalah video dengan caption “Janganlah engkau S H O M B O N G! karena diatas langit masih ada @hotmanparioffical". Video berdurasi 59 detik tersebut berisi tentang Helen yang memberikan nasihat agar tidak sombong, namun malakukan hal sebaliknya dengan cara yang unik dan khas caranya berbicara.

Dalam video tersbeut Helen itu bekata "kalian tau nggak, kita tuh nggak boleh membanggakan diri menyombongkan diri dan memperlihatkan diri kita kelebihan kita kepada para sekitar sobat. Apapun yang baru kita dapatkan simpanlah baik-baik itu yah, tolong ingat nasihat aku. Kayak kemaren tiga hari yang lalu aku baru beli hape, cukup kita aja yang tau, orang lain tu nggak perlu tau, kemaren aku beli hape I-Phone XR cukup kita aja yang tau, orang lain tu rasanya nggak perlu tau apa yang kita beli, kayak hari ini aku baru pasang kuku cukup kita aja yang tau jangan sampai orang lain tau apapun yang kita lakukan karna sombong itu sangat tidak baik. Kayak ginilah kira-kira bentu kukunnya, jangan kasih nampak sama orang lain cukup untuk diri kita aja, kepuasan diri kita orang tu nggak perlu tau kalo kita baru pasang kuku ke salon, jangan sayang. Pokoknya kayak gitulah kira-kira nasihat dari aku, kayak tadi aku baru beli baju, jangan sampai orang lain tau karna diatas langit masih ada Hotman Paris."

Video yang diupload pada tanggal 22 Maret 2019 tersebut berhasil menarik perhatian dan ditonton oleh lebih dari 400.000 pengguna Instagram, dengan 49.506 likes dan lebih dari 4000 komentar. Meski ada juga video dalam akun@helenjunet yang mendapatkan lebih banyak views, likes dan komentar, tetapi video ini dapat dijadikan perbandingan dengan video-video lainnya yang masuk kedalam kategori video viral dengan fenomena mikro-selebriti.

Jika melihat akun @helejunet sendiri, akun tersebut memang sudah terkenal dilihat dari jumlah followers-nya yang mencapai lebih dari 240.000 followers yang menunjukkan bahwa akun tersebut dapat menginterpretasikan bagaimana fenomena mikro-selebriti itu terjadi melaui videonya yang menjadi viral. Selain itu akun @ helenjunet juga terkenal setelah banyak memposting video-video serupa yang dia nggap lucu dan menarik perhatian publik dengan gaya bicara dan raut wajah yang menjadi ciri khasnya dalam setip postingannya.

Selain itu, postingan akun @ helenjunet dilihat dari berbagai video- 
video yang di-posting juga konsisten dengan tujuan nya untuk menghibur dengan gaya dan ciri khas yang dia punya serta berbeda dengan kebanyakan akun hiburan lainnya yang hanya memposting video viral yang hanya mengandung kontroversi semata.

Di sisi lain akun-akun hiburan yang khusus memposting video-video viral juga mulai bermunculan seiring dengan banyaknya video-video yang menarik atensi publik atau singkatnya video yang viral yang mengandung unsur mikro-selebriti. Dan selama peneliti melakukan riset, dalam akun-akun tersebut juga terdapat postingan-postingan berupa videovideo lainya yang bahkan sudah dilihat hingga puluhan ribu kali dalam 24 jam setelah posting.

Pada video akun@helenjunet yang di reupload oleh akun-akun tersebut, dari sudut pandang peneliti konten dan pesan yang ingin disampaikan oleh Helen selaku pembuat video masih bisa terlihat hanya saja cara pengungkapannya unik dan berbeda dari yang lain dan masih dalam satu manfaat instagram sebagai sosial media yang berfungsi untuk menghibur.

Namun di sisi lain, peneliti juga menemukan banyak postingan video di instagram yang akhirnya menjadi viral dan di upload oleh akun-akun hiburan populer dan diakses oleh banyak pengguna lain yang kontennya sangat tidak mendidik, diikuti kata-kata kasar dan terbilang ekstrem serta tidak memiliki nilai informasi sama sekali tetapi berhasil viral karena kontroversi sehingga banyak orang yang menonton hanya karena dianggap "konyol" oleh sebagian orang.

Tak hanya satu, akun-akun serupa seperti banyak ditemukan di instagram dan jika dilihat dari sudut pandang berbeda, hal itu dapat dijadikan acuan, bahwa dengan membuat video-video seperti itu seseorang akan dengan mudah mendapat perhatian dan menyita atensi publik, lalu viral di media sosial.

Dengan modal bicara lalu berujung menjadi viral, bahkan sampai melakukan hal ekstrem hanya untuk menarik perhatian public, hal itu menarik perhatian penulis untuk menelaah apa sebenarnya faktor video-video serupa dapat memiliki penonton bahkan hingga belasan hingga puluhan ribu.

Ditambah lagi melalui akun-akun hiburan tersebut memiliki ribuan like dan views di setiap postingan videonya, menjadikan tren mikro-selebriti kian menjamur. Orang berlomba-lomba membuat video-video dengan berbagai konsep agar videonya dapat viral dan 
dilihat oleh banyak orang. Kehadiran instagram saat ini tidak bisa dipisahkan dari kehidupan masyarakat, dan bahkan hal itu bersifat heterogen dan tak lagi memandang batasanbatasan usia bagi penggunanya.

Williamson sebagimana dikutip Widjajanto (2013: 143) menyatakan bahwa media sosial adalah media yang dide-sain untuk menyebarkan pesan melalui interaksi sosial dan dibuat dengan tek-nik-teknik publikasi yang sangat mudah diakses dan berskala besar.

Namun unggahan seperti video viral tersebut seakan-akan memaksa beberapa ranah digabung kedalam satu ruang sosial. Instagram yang pada kenyataannya merupapakan ruang komunikasi publik yang dapat dimanfaatkan untuk mengeksplor hal positif terkait dengan informasi publik tiba-tiba berubah menjadi ajang kompetisi untuk meperoleh penggemar dan pengakuan publik dengan malakukan halhal di luar norma agar mendapat perhatian dari banyak orang.

Hal-hal yang dijelaskan diatas yang memicu menjamurnya tren video viral di media sosial terutama di instagram dan dapat memicu munculnya sudut pandang yang berbeda juga dari viewers atau orang-orang yang mengkonsumsi video tersebut baik secara sengaja mengaksesnya, maupun tidak.
Secara perangkat, viralnya videovideo tersebut juga dikarenakan tersedianya fitur di media social, dalan hal ini instagram yang memungkinkan pengguna secara langsung menyebarkan, baik melalui jejaring pertemanan maupun di luar itu.

Dan jika melihat jaringan social yang berada di media sosial terutama di instagram, jumlah pengguna instagram tentu menjadi faktor penting dari meyebarnya video-video tersebut sebagai sebuah tren micro-celebrity yang muncul di instagram.

Selain itu, fitur komentar dimana parapengguna lain dapat mengungkapkan pendapatnya terkait dengan postingan yang diunggah dapat mewakili terkait dengan bagaimana mereka menyikapi tren micro-celebrity yang terjadi di instagram.

Dalam video yang dipaparkan sebelumnya oleh penelti, komentarkomentar yang bermunculan juga beragam, mulai dari yang menanggapinya sebagai hiburan dengan menuliskan komentar lewat emotikon tertawa, ada pula yang mengutarakan perasaannya seperti menuliskan komentar "pengen bener nyenti empedunya" bahkan ada 
yang menghujat atau bahkan menandai orang lain agar melihat video tersebut.

Aktivitas-aktivitas tersebutlah yang memicu munculnya budaya cyber, dimana budaya pengguna dapat dilihat dari komentarkomentar yang ditulis oleh pengguna dalam video-video tersebut. Kecenderungan komentar-komentar pengguna tersebut dapat memperlihatkan bagaimana budaya siber yang tercipta di kalangan para pengguna instagram, terutama yang mengikuti dan memperhatikan bagaimana para mikro-selebriti bertindak dalam ranah siber.

Hal ini sesuai dengan apa yang dikemukakan oleh Bell bahwa Ibarat dua sisi mata uang, ketika pengguna beraktivitas di media sosial, pada saat itu juga aktan (pengguna, teknologi, perangkat sampai pada konten yang dihasilkan) telah berada dalam mesin produksi kebudayaan dan sekaligus sebagai komoditas dari kebudayaan itu sendiri. Karena itu, Bell, $(2001 ; 8)$ menegaskan bahwa ruang siber (cyberspace) merupakan budaya siber (cyberculture), begitu juga sebaliknya. (Nasrullah, 2015; 74)

Dari dinamika dan kompleksitas fenomena diatas, maka penulis akan menarik dan menjelajahi lebih jauh dengan penelitian yang yang berjudul Fenomena Mikro-Selebriti di Media Sosial (Studi Etnografi Virtual Video
Viral Akun @helenjunet Tanggal 22 Maret 2019 Pada Pengguna Instagram)

TINJAUAN PUSTAKA

\section{A. Landasan Teoritis}

\section{Etnografi Virtual}

"Etnografi virtual merupakan metode etnografi yang dilakukan untuk melihat fenomena sosial atau kultur pengguna di ruang cyber. Bahkan Bell (2001) menyatakan bahwa, metode etnografi ini merupakan metode utama dan penting untuk melihat fenomena budaya siber di internet. Oleh karena itu, dalam kajian etnografi virtual, pola pendekatan penelitian terhadap internet bisa dilakukan tergantung dari bagaimana individu memandang internet." (Nasrullah, 2014:171)

\section{Budaya Siber (Cyberculture)}

"Budaya siber atau cyberculture secara sederhana melihat bagaimana budaya itu berada di ruang cyber. Dalam buku Ruli Nsrullah "Komunikasi Antar Budaya di Era Budaya Siber (2012)" bahwa internet merupakan ruang di mana budaya yang terjadi itu diproduksi, didistribusikan dan dikinsumsi. Media 
sosial juga bisa dilihat sebagai medium tempat budaya siber berada dan melalui media sosial juga dapat diketahui artefak budaya siber itu berkembang. Dengan demikian. Melihat budaya siber dan media sosial harus diawali dengan sebuah konsep atau sudut pandang bahwa media sosial merupakan sebuah produk dari budaya dan sekaligus sebagai produser dari budaya itu sendiri.” (Bell,2001)

"Ibarat dua sisi mata uang, ketika pengguna beraktifitas di media sosial, pada saat itu juga pengguna, teknologi, perangkat sampai pada konten yang dihasilkan telah berada dalam mesin produksi kebudayaan dan sekaligus sebagai komoditas dari kebudayaan itu sendiri. Karena itu, Bell, (2001;8) menegaskan bahwa ruang siber (cyberspace) merupakan budaya siber (cyberculture), begitu juga sebaliknya." (Nasrullah, 2015 ; 74)

"Budaya pada dasarnya merupakan nilai-nilai yang muncul dari proses interaksi antar individu. Nilai-nilai ini diakui, baik secara langsung maupun tidak, seiring dengan waktu yang dilalui dalam interaksi tesebut. Bahkan terkadang sebuah nilai tersebut berlangsung didalam alam bawah sadar individu dan diwariskan pada generasi berikutnya. Berdasarkan beberapa prespektif, budaya dapat disimpilkan sebagai sebuah nilai atau praktik sosial yang berlaku dan dipertaruhkandalam hubungan antar manusia, baik sebagai individu maupun sebagai anggota masyarakat.” (Nasrullah, 2015 ; 74)

"Secara sederhana, kata "siber" menunjuk pada apa yang ada di internet. Namun, tidak hanya sebuah internet sebagai sebuah perangkat teknologi yang termasuk ke dalam konteks siber tersebut, tetapi juga interaksi, komunikasi, data, perangkat antarmuka, sampai pada penggunanya. Dalam pandangan Luke (dalam Bell, 2001:17), ruang siber ibarat hyperreal state dimana ruang ini dimiliki, diatur sampai dikontrol, baik melalui sistem jaringan kabel maupun nirkabel (wireless), dengan menggunakan perangkat teknologi." (Nasrullah, 2015 : 77)

"Dari penjelasan-penjelasan tersebut dapat ditarik kesimpulan, apa yang dimaksud dengan budaya siber (cyberculture), secara sederhana bisa dimaknai dengan; praktik sosial maupun nilai-nilai dari komunikasi dan interaksi antar pengguna yang muncul di ruang siber dari hubungan 
antar manusia dan teknologi maupun antar manusia .dengan perantara teknologi. Budaya itu diproduksi, didistribusikan, dan dikonsumsi melalui jaringan internet dan jaringan yang terbentuk di antara pengguna." (Nasrullah, 2015: 78).

\section{Level Analisi Media Siber}

$\begin{array}{cccr}\text { "Rulli } & \text { Nasrullah } & \text { dalam bukunya } \\ \text { "Etnografi } & \text { Virtual } & \text { sebagai } & \text { Riset }\end{array}$

Komunikasi, Budaya dan Sosioteknologi di Internet" menawarkan sebuah metode dalam menguraikan budaya dan artefak budaya di Internet. Metode Analisi Media Siber (AMS) merupakan perpaduan sekaligus memandu proses menganalisis etnografi virtual. Setiap level dalam AMS memberikan gambaran bagaimana komnitas vitrual yang ada di internet." (Nasrullah, 2018 ; 44)

"Pada satu sisi, metode AMS mengolaborasikan oflline dan online ke dalam lokasi penelitian. Namun pada lain sisi, setiap bagian bisa berdiri sendiri secara independen dan menjadi level-level tertentu sesuai dengan fokus dari etnografer." (Nasrullah, 2018 ; 44)

"Pada prinsipnya, dalam menganalisis budaya di internet, AMS memerlukan unit analisis, baik pada level mikro maupun makro. Dua unit analisis ini bisa disederhanakan dalam teks dan konteks. Di level mikro peneliti menguraikan bagaimana perangkat internet, tautan yang ada, sampai halhal yang bisa dilihat di permukaan. Sementara di level makro peneliti melihat konteks yang ada dan menyebabkan teks itu muncul serta alasan yang menorong kemunculan teks tersebut. level mikro-makro pada praktiknya terbagi menjadi empat level, yakni ruang media (media space), dokumen media (media archive), objek media (media object) dan pengalaman (experiantial stories) sebagaimana dijelaskan dalam gambar berikut":

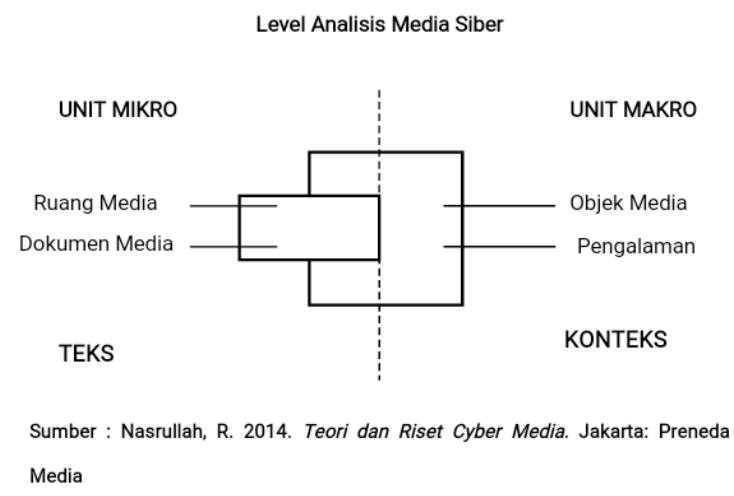

\section{Level Ruang Media}

"Dalam ruang medai, level ini mengungkapkan bagaimana struktur yang ada dari medium internet. Medium ini merupakan lokasi atau 
tempat budaya terjadi dan komniatas berinteraksi. Jika mengambil contoh media sosial, prosedur mebutat akun, memublikasikan konten, maupun aspek grafis dari tampilan media menjadi salah satu deskripsi yang perlu dijelaskan dalam laporan penelitian." (Nasrullah, 2018 : 4455)

\section{Level Dokumen Media}

"Level dokumen media digunakan untuk melihat bagaimana sisi -sebagai sebuah teks dan makna yang terkandung di dalamnya - diproduksi dan disebarkan melalui internet. Level ini pada dasarnya menjawab faktor apa yang menjadi artefak budaya dalam penelitian etnografi virtual . teks yang dibangun oleh pengguna (encoding) menjadi sorotan penting dalam level ini untuk diterjemahkan (decoding). Di level ini etnografer bisa mengeksplorasi artefak-artefak budaya dan bagaimana entitas itu meproduksi sebagai bagian dari interaksi dalam komunitas virtual." (Nasrullah, $2018:$ 44-55)

\section{Level Objek Media}

"Padal level ini objek media merupakan unit yang spesifik karena peneliti bisa melihat bagaimana aktivitas dan interaksi pengguna atau antar pengguna, baik dalam unit mikro maupun makro.
Dalam level ini data penelitian bisa derasal dari teks yang ada di media siber maupun konteks yang berada disekitar teks tersebut. jika pada level dokumen peneliti hanya mrmfokuskan pada teks dari produser, pada level ini peneliti mengalihkan pada bagaimana teks itu ditanggapi atau berinteraksi dengan pengguna siber lainnya." (Nasrullah, $2018:$ 44-55)

\section{Level Pengalaman}

"Level pengalama atau (expetieniel stories) merupakan gambaran secara makro bagaimana masyarakat atau anggota komunitas itu di dunia offline. Ini dimaksudkan bahwa apa yang muncul di online memiliki relasi dengan dunia nyata. Di level ini peneliti bisa menghubungkan realitas yang terjadi di dunia virtual (online) dengan realitas yang ada di dunia nyata." (Nasrullah, 2018 : 4455)

\section{B. Landasan Konseptual}

\section{New Media (Media Baru)}

Istilah "media baru" (new media) telah digunakan sejak tahun 1960-an dan telah mencakup 
seperangkat teknologi komunikasi terapan yang semakin berkembang dan beragam. Menurut McQuail (2010:130) media baru adalah tempat dimana sema pesan komunikasi terdesentralisasi, distribusi pesan lewat atelit dapat meningkatkan penggunaan jaringan kabel dan komputer serta keterlibatan audience dalam proses komunikasi semakin meningkat."

Menurut McQuail (2010:130) "media baru adalah tempat dimana sema pesan komunikasi terdesentralisasi, distribusi pesan lewat atelit dapat meningkatkan penggunaan jaringan kabel dan komputer serta keterlibatan audience dalam proses komunikasi semakin meningkat.”

McQuail (2010:141) lebih lanjut mengatakan bahwa "media baru telah menimbulkan prubahan di bidang digitalisasi dan perubahan-perubahan penting lainnya yang berhubungan dengan munculnya media baru, yaitu; pertama, digitalisasi dan konvergengsi semua aspek dari media. Kedua, interaktivitas dan konektivitas jejaring yang meningkat. Ketiga, mobilitas dan delokasi pengiriman dan penerimaan (pesan). Keempat, adaptasi publikasi dan peran-peran khalayak. Kelima, munculnya beragam bentuk baru dari media gateway, yaitu pintu masuk untuk mengakses informasi pada web atau untuk mengakses web itu sendiri. Terakhir, fragmentasi dan meleburnya institusi media."

\section{Instagram}

Menurut Atmoko (2012: 10) "Instagram adalah sebuah aplikasi dari Smartphone yang khusus untuk media sosial yang merupakan salah satu dari media digital yang mempunyai fungsi hampir sama dengan twitter, namun perbedaannya terletak pada pengambilan foto dalam bentuk atau tempat untuk berbagi informasi terhadap penggunanya. Instagram juga dapat memberikan inspirasi bagi penggunanya dan juga dapat meningkatkan kreatifitas, karena instagram mempunyai fitur yang dapat membuat foto menjadi lebih indah, lebih artistik dan menjadi lebih bagus."

\section{Viral}

"Kata "Viral" sebenarnya sudah muncul dan digunakan sejak tahun 1944 silam. Kata tersebut berasal dari bahasa asing (Bahasa Inggris) yang artinya "segala sesuatu yang berhubungan dengan virus". Sedangkan arti virus dalam Kamus 
Besar Bahasa Indonesia (KBBI) merupakan istilah yang berasal dari bidang kedokteran untuk menyebutkan mikroorganisme yang tidak dapat dilihat dengan kasat mata yang dapat menyebarkan penyakit tertentu kepada makluk hidup khususnya manusia dan hewan. Namun, akhir-akhir ini kata virus itu digunakan untuk menyebutkan sebuah software illegal yang masuk kedalam sebuah sistem komputer yang dapat merusak program yang ada di dalamnya."

"Sedangkan arti kata viral yang berhubungan dengan internet yaitu untuk menggambarkan atau menjelaskan sesuatu yang sangat cepat menjadi populer di kalangan pengguna internet khususnya media sosial dengan cara mempublikasikan atau menyebarkan sebuah cuplikan informasi, foto, ataupun video yang dibuat oleh seseorang."

\section{Mikro-selebriti}

"Media sosial telah memberikan kesempatan kepada orang-orang untuk menjadi terkenal dan dianggap dalam sebuah kelompok pengguna media tertentu (Marwick \& Boyd, 2011). Pendapat ini membawa kemunculan konsep mikroselebriti, yang dimaknai sebagai individu-individu yang berkompetisi untuk memperoleh penggemar dan pengakuan di media sosial (Marwick \& Boyd, 2011). Untuk menjadi seorang mikroselebriti, seseorang perlu memiliki kemampuan untuk menangkap atensi khalayak “(Cultureshop, 2015).

"Seseorang dapat disebut sebagai mikroselebriti bila Ia memiliki jumlah followers yang sangat banyak dan namanya dikenal oleh banyak pengguna media sosial. Berikut adalah pengertian mikroselebriti dari Marwick \& Boyd: “

"Micro-celebrity is an emerging online practice that involves creating a persona, sharing personal information about oneself with others, performing intimate connections to create the illusion of friendship or closeness, acknowledging an audience and viewing them as fans, and using strategic reveal of information to increase or maintain this audience." (Marwick \& boyd, New Media \& Society, 2010).

\section{METODOLOGI PENELITIAN}

"Pemelitian ini menggunakan pendekatan konstruktivisme. Menurut Eriyanto (2004:13) paradigma konstruktivisme ialah paradigma dimana kebenaran suatu realitas sosial 
dilihat sebagai hasil konstruksi sosial, dan kebenaran suatu realitas sosial bersifat relatif. Paradigma konstruktivisme ini berada dalam perspektif interpretivisme (penafsiran) yang terbagi dalam tiga jenis, yaitu interaksi simbolik, fenomenologis dan hermeneutik. Paradigma konstruktivisme dalam ilmu sosial merupakan kritik terhadap paradigma positivis."

"Metodologi yang digunakan adalah metodologi penelitian kuanlitatif. Menurut Sulistyo-Basuki, (2006:78) penelitian kualitatif bertujuan memperoleh gambaran seutuhnya mengenai suatu hal menurut pandangan manusia yang diteliti. Penelitian kualitatif berhubungan dengan ide, persepsi, pendapat, atau kepercayaan orang yang diteliti; kesemuanya tidak dapat diukur dengan angka “

"Sedangkan pada penelitian ini, objek penelitiannya adalah para pengguna media sosial instagram dan kecendrungannya dalam mengkonsumsi video yang mengandung micro-celebrity di instagram. Sesuai dengan pengertian menurut Ulber Silalahi, (2009: 191) bahwa fenomena atau masalah penelitian yang telah diabstraksi menjadi suatu konsep atau variabel disebut sebagai objek penelitian.”
"Dan untuk kriteria informan, dalam penelitian ini penulis menggunakan metode purposive sampling, dimana peneliti cenderung memilih informan yang dianggap memenuhi kriteria dalam menguasai informasi dan masalahnya secara mendalam dan dapat dipercaya menjadi sumber data yang akurat. “(Kriyanto, 2012:158)

\section{PEMBAHASAN}

\section{A. Analisis Dan Pembahsan}

Pada level ruang media (Media Space) video viral milik Helen tersebut bisa didapatkan di beberapa akun lain karena sudah banyak di repost atau diupload ulang oleh berbagai akun, mulai dari akun hiburan yang memang kerap mengunggah video viral, bahkan hingga akun pribadi sekalipun dan juga mendapatkan views dengan jumlah beragam.

Saat suatu video menjadi viral dan di posting ulang oleh aku yang berbeda-beda, maka secara dasar caption atau keterangan foto atau video juga akan berbeda sesuai dengan kemauan pengirim. 
Perbedaan caption tersebutlah yang merujuk pada level dokumen (Media Arhive) dimana hal itu dapat dijadikan acuan sebagai suatu hal yang dirasakan oleh pemilik akun yang melakukan repost. Sama halnya dengan caption, komentar-kmentar yang muncul juga beragam dan mewakili perasaan pengguna instagram lainnya yang melihat video tersebut.

Melelui capture komentar, peneliti menemukan bahwa pada level objek media (Media Object) komentar-komentar yang ditulis oleh para viewers video tersebut juga menunjukkan bagaimana gambaran dari realitas offline yang dituangkan dalam bentuk teks secara online pada ruang siber.

Komentar-komentar yang muncul sangat beragam, mulai dari komentar yang menganggapnya menghibur, komentar menandai, komentar reply, komentar menghujat hingga komentar yang membela. Dengan berbagai motif tersebut merujuk pada level pengalaman (Experiential Stories) dimana ragam komentar tersebut mewakili realitas offline yang terjadi. Dimana seseorang dalam lingkup media sosial cenderung subjektif terhadap apa yang dilihatnya.

\section{KESIMPULAN}

Berdasarkan hasil penelitian dan analisis data yang telah peneliti paparkan sebelumnya, maka peneliti menarik kesimpulannya sebagai berikut:

1. Peneliti menemukan bahwa pengguna istagram yang melihat video viral Helen entah itu yang melihatnya karena mengikuti akun@ @helenjunet maupun yang melihatnya secara tidak sengaja melalui explore dan lain-lain, akan melakukan sesuatu sebagai bentuk prilaku respon terhadap video tersebut melaui fitur yang disediakan oleh instagram mulai dari like, komentar, share, hingga memposting ulang dengan menyertakan tagar dan caption yang berbeda. Melalui prilaku dan respon tersebut, dapat menunjukkan bagaimana pengguna instagram memaknai tren mikroselebriti yang terkandung dalam video tersebut.

2. Budaya pengguna muncul akibat perilaku yang terus menerus dilakukan oleh pengguna. Perilaku pengguna saat merespon dengan menekan tombol like, berkomentar hingga membagikan postingan dan memposting ulang dengan menggunakan hashtag atau tagar dan terjadi terus menerus tersebutlah yang pada akhirnya menjadi budaya yang terjadi di ruang cyber Instagram saat dihadapkan pada 
video viral yang mengandung unsur mikroselebriti. Budaya like, komentar, share dan repost, hingga budaya menggunakan tagar atau hashtag dapat dilihat secara mendetail tentang bagaimana pengguna instagram memaknai video viral @helenjunet yang mengandung unsur mikro-selebriti sebagai sesuatu yang pantas diberika respon dan feedback.

3. Dengan adanya kecenderungan perilaku dan budaya pengguna di ruang siber, peneliti juga menemukan beberapa motif yang menjadi alasan para pengguna instagram menonton dan mengikuti tren video viral. Pertama, motif hiburan dimana video-video viral di tonton karena dianggap lucu dan menghibur menjadi alasan utama pengguna di instagram bertahan dan memperhatikan tren video viral yang mengandung unsur mikro-selebriti di instagram. Beberapa dari mereka bahkan mengaku memfollow akunakun yang kerap mengunggah video viral untuk mengisi waktu luang ketika mengunjungi media sosial. Kedua, motif keingintahuan dimana alasan ini muncul akibat adanya pandangan antar pengguna instagram bahwa 'seseorang yang tidak tahu apa yang sedang populer dan viral di media sosial merupakan orang yang tidak uptodate'. Walaupu pada kasus ini pengguna akhirnya menikmati apa yang dilihatnya tanpa adanya paksaan, namun hal ini terjadi karena adanya dorongan awal yang membuat mereka memperhatikan fenomena mikro-selebriti pada videovideo viral di instagram secara masif.

\section{SARAN}

Setelah penelitian ini dilakukan, peneliti menyadari bahwa fenomena mikro-selebriti pada video viral $d$ instagram memiliki pengaruh besar terhadap aktivitas pengguna instagram, dimana hal itu dapat menjadi sebuah tren yang mengukur seberapa uptodate penggunanya.

Berbeda dengan status di facebook atau twitter, instagram lebih banyak memiliki ruang yang dapat digunakan oleh pengguna dan memicu terjadinya interaksi dan budaya siber lebih terlihat pada fenomena mikro-selebriti yang viral di instagram. Namun hal itu juga yang menyebabkan pesan sesungguhnya yang ingin disamapaikan melalui postingan video viral masih sulit untuk dimaknai secara positif. Begitu juga dengan emosi penggunanya saat menanggapi videovideo tersebut menggunakan kata-kata kasar yang dituliskan secara gamblang pada kolom komentar. 
Peneliti juga menyadari bahwa pembahasan tentang fenomena mikro-selebriti di Indonesia masih sangat minim, padahal fenomena mikro-selebriti sudah banyak terjadi di berbagai platform sosial media selain instagram.

Peneliti berharap di waktu selanjutnya penelitian tentang mikro-selebriti lebih banyak dilakukan di Indonesia untuk mendukung referensi penelitian dalam jangka panjang. Sedangkan untuk peneliti selanjutnya, peneliti menyarankan agar dilakukan riset perbandingan fenomena mikro-selebriti pada ruang siber yang berbeda sehingga temuannya juga akan berkembang.

\section{DAFTAR PUSTAKA}

\section{Sumber Buku :}

Atmoko, Bambang Dwi. 2012. Instagram Handbook. Jakarta: Media Kita

Clarewells, D. 2014. Mikro-selebriti dan Media Sosial. Jakarta. Mizan

Cultureshop. 2015. The Rise of Microcelebrity: Why Brands Should Tap Into This Cultural Phenomenon.

Eriyanto. 2004. Analisis Wacana: Pengantar Analisis Isi Media. Bandung. PT.Remaja Rosdakarya

Kriyantono, Rachmat. 2010. Teknis Praktis Riset Komunikasi. Jakarta. Kencana Prenada Media
Marwick, A., \& Boyd, d. 2011. To See and Be Seen: Celebrity Practice on Twitter. Convergence: The International Journal of Research into New Media Technologies .

McQuail, Denis. 2010. Teori Komunikasi Massa McQuail, Edisi 6 Buku 1. Jakarta: Salemba Humanika

Nasrullah. Rulli. 2014. Teori dan Riset Media Siber. Jakarta. Kencana Prenadamedia Group.

Nasrullah. Rulli. 2015. Media sosial : prespektif komunikasi, budaya, dan sosioteknologi. Bandung : Simbiosa Rekatama Media

Nasrullah, R. 2012. Komuniaksi Antarbudaya : Di Era media Siber. Jakarta. Pranadamedia Group

Nasrullah. R. 2018. Etnografi Virtual: Riset Komunikasi, Budaya, dan Sosioteknologi di Internet. Bandung. Simbiosa Rekatama Media

Silalahi, U. 2009. Metode Penelitian Sosial. Bandung. PT. Refika Aditama

Widjajanto, Kenmada. 2013. Perencanaan Komunikasi: Konsep dan Aplikasi. Bandung: CV Ultimus. 